May $2000 \quad$ N NREL/CP-520-28426

\title{
Customer Sited PV - U.S. Markets Developed from State Policies
}

C. Herig and $\mathrm{H}$. Thomas

National Renewable Energy Laboratory: Golden, Colorado

R. Perez

ASRC: The University at Albany; New York

$\mathrm{H}$. Wenger

AstroPowerWest: Concord, California

Presented at the 16th European

Photovoltaic Solar Energy Conference and Exhibition Glasgow, Scotland, U.K.

May 1-5, 2000

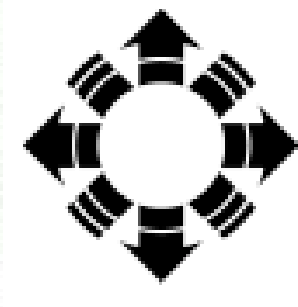

\section{NPEI}

National Renewable Energy Laboratory

1617 Cole Boulevard

Golden, Colorado 80401-3393

NREL is a U.S. Department of Energy Laboratory

Operated by Midwest Research Institute $\bullet$ Battelle $\bullet$ Bechtel

Contract No. DE-AC36-99-G010337 


\section{NOTICE}

The submitted manuscript has been offered by an employee of the Midwest Research Institute (MRI), a contractor of the US Government under Contract No. DE-AC36-99G010337. Accordingly, the US Government and MRI retain a nonexclusive royalty-free license to publish or reproduce the published form of this contribution, or allow others to do so, for US Government purposes.

This report was prepared as an account of work sponsored by an agency of the United States government. Neither the United States government nor any agency thereof, nor any of their employees, makes any warranty, express or implied, or assumes any legal liability or responsibility for the accuracy, completeness, or usefulness of any information, apparatus, product, or process disclosed, or represents that its use would not infringe privately owned rights. Reference herein to any specific commercial product, process, or service by trade name, trademark, manufacturer, or otherwise does not necessarily constitute or imply its endorsement, recommendation, or favoring by the United States government or any agency thereof. The views and opinions of authors expressed herein do not necessarily state or reflect those of the United States government or any agency thereof.

Available electronically at http://www.doe.gov/bridge

Available for a processing fee to U.S. Department of Energy and its contractors, in paper, from:

U.S. Department of Energy

Office of Scientific and Technical Information

P.O. Box 62

Oak Ridge, TN 37831-0062

phone: 865.576 .8401

fax: 865.576.5728

email: reports@adonis.osti.gov

Available for sale to the public, in paper, from:

U.S. Department of Commerce

National Technical Information Service

5285 Port Royal Road

Springfield, VA 22161

phone: 800.553 .6847

fax: 703.605.6900

email: orders@ntis.fedworld.gov

online ordering: http://www.ntis.gov/ordering.htm

Printed on paper containing at least $50 \%$ wastepaper, including $20 \%$ postconsumer waste 


\title{
CUSTOMER SITED PV-U.S. MARKETS DEVELOPED FROM STATE POLICIES
}

\author{
Christy Herig \& Holly Thomas \\ National Renewable Energy Laboratory \\ 1617 Cole Boulevard \\ Golden, CO USA 80401- 3393 \\ christy_herig@nrel.gov
}

\author{
Richard Perez \\ ASRC \\ The University at Albany 251 Fuller Rd \\ Albany, NY 12203 \\ perez@asrc.cestm.albany.edu
}

\author{
Howard Wenger \\ AstroPowerWest \\ 5036 Commercial Circle, Suite B \\ Concord, CA 94520 \\ hwenger@astropower.com
}

\begin{abstract}
The customer-sited PV market in the United States depends on state policies emerging from electric utility industry restructuring. These policies, most of which have appeared since 1996, reduce both the first cost and improve operating benefits. This analysis determines the breakeven turnkey cost of a PV system, from the customer ownership perspective, on a state-by-state basis. The results of this work are used by industry to target high-value markets and by policy makers to identify options that will result in the greatest economic and market development. Still intangible external PV benefits, such as environmental value, are also analyzed and gauged against existing/potential policy actions.
\end{abstract}

\section{INTRODUCTION}

The U.S. market for customer-sited photovoltaics (CSPV) has historically been off-grid systems where the capital cost of the distribution-line extension offsets the CSPV cost. With residential energy prices ranging from $5 \phi-14 \phi / \mathrm{kWh}$, a consumer's values must extend beyond economics to make a grid-connected CSPV investment. PV system installed costs have declined from $\$ 6.21 / \mathrm{W}$ in 1996 to $\$ 3.90 / \mathrm{W}$ in $2000,{ }^{1}$ with levelized energy costs of $17 \phi-12 \phi / \mathrm{kWh}^{2}$ respectively [5]. Additionally, the PV industry has developed products targeted at the grid-tied residential market and developed financing packages to alleviate the up-front cost burden to the consumer. The gap between consumer value and cost for CSPV is close, but not close enough for most U.S. consumers. However, as part of the electric industry restructuring, many states have included grid-tied CSPV market development policies for the purposes of resource diversity and economic development. The initial customer-sited PV niche market analysis completed in 1996 [1] resulted in only 5 states with a breakeven turnkey cost (BTC) greater than $\$ 4$ per watt. In 1999, 15 states had BTCs greater than $\$ 4$ per watt, and four states were above $\$ 7$ per watt. This increase in consumer market value is fully attributed to policies emerging from state restructuring activities. These include:

- 9 state income tax rebates

- 30 states with net metering [6]

- 12 buy-down or grant programs

- 11 property tax exemptions

- 2 state interconnection standards.

Including these incentives in a life-cycle value analysis for CSPV provides industry with geographic market targets.

\footnotetext{
${ }^{1}$ These costs are the result of an aggregate long-term purchase for the Sacramento Municipal Utility District Pioneer PV program and represent the lowest reported residential installed costs. These are representitive of commercial PV systems of $30 \mathrm{~kW}$ or more. The year 2000 cost was estimated from the committed contract price.

${ }^{2}$ Levelized costs are for residential systems with $1{ }^{\text {st }}$ mortgage financing and retail rate compensation for energy production at $10 \notin / \mathrm{kWh}$
}

\section{APPROACH}

The state-by-state database was developed to determine a breakeven turnkey cost for each state and is presented in Table 1. The consumer breakeven turnkey cost (BTC) is the value per $\mathrm{kW}$ that a consumer can pay for a PV home energy system and neither gain nor lose money over the life of the system. The energy, tax, and policy benefits, as well as the capital (included in the home mortgage), operation, and maintenance costs over the life of the system are forced to a net present worth of zero, using an $8 \%$ discount rate, by varying the initial cost of the PV system.

\subsection{Assumptions}

With comparisons made later in the paper between the 1996 analysis and 1999 analysis, it should be noted that many of the assumptions for the life-cycle value analysis were more conservative for the 1999 analysis. The electricity price inflation rate has been lowered from $3.5 \%$ to $2 \%$, consistent with market realities. This change decreased the BTC 5\%-10\%. However, operation and maintenance costs are still inflated at 3.5\%. An inflation rate was not applied to the environmental externality benefits over the life of the system, because this is still an intangible value. Also consistent with the 1996 analysis is the 1-kW installed PV system basis, taking advantage of full residential retail electric rate benefits. The mortgage financing is at $90 \%$ debt, 30-year term, but the interest rate is set at $7 \%$, down from $8 \%$, which results in an increased BTC.

\subsection{Database Development}

Next to capital cost reduction policy incentives, the analysis is most sensitive to changes in the residential rates. The current residential rates are based on annual residential revenue and consumption [3], resulting in lower, more conservative rates. Of the 50 states, only 21 rates changed from the initial study by one- or two-tenths of a cent. 
Table 1: State-By-State Attributes and Incentives

\begin{tabular}{|c|c|c|c|c|c|c|c|c|c|c|c|c|c|c|}
\hline State & \begin{tabular}{|l|} 
Res. \\
Rank \\
1999 \\
\end{tabular} & \begin{tabular}{|c|} 
Res. \\
Rate \\
{$[3]$} \\
\end{tabular} & \begin{tabular}{c|} 
Res. Tax \\
Credit $[4],[5]$
\end{tabular} & $\begin{array}{c}\text { Net } \\
\text { Meter } \\
{[6]}\end{array}$ & $\begin{array}{c}\text { Prop- } \\
\text { erty } \\
\text { Tax } \\
{[3]}\end{array}$ & $\begin{array}{c}\text { Sales } \\
\text { Tax } \\
{[3]}\end{array}$ & $\begin{array}{c}\text { Buy } \\
\text { Down, } \\
\text { Grant }[5], \\
{[7],[8],[9]}\end{array}$ & \begin{tabular}{|c|} 
SOX- \\
$\# / \mathrm{kW}-$ \\
$\mathrm{yr}[10]$
\end{tabular} & \begin{tabular}{|c|} 
NOX- \\
$\# / k W-$ \\
$\mathrm{yr}[10]$
\end{tabular} & $\begin{array}{c}\mathrm{CO} 2- \\
\# / \mathrm{kW}- \\
\mathrm{yr}[10]\end{array}$ & \begin{tabular}{|c|} 
Cap \\
Factor \\
{$[11]$}
\end{tabular} & $\begin{array}{c}\text { Res. } \\
\text { BTC } \\
(\$ / \mathrm{kW}) \\
1999\end{array}$ & $\begin{array}{c}\text { Ext. - } \\
\text { NPV } \\
(\$ / k W) \\
1999\end{array}$ & $\begin{array}{c}\text { Res. } \\
\text { BTC } \\
(\$ / \mathrm{kW}) \\
1996\end{array}$ \\
\hline Alaska & 39 & 11.4 & & & & & & 5 & 10 & 2644 & 12 & $\$ 2,462$ & $\$ 413$ & $\$ 1,793$ \\
\hline Arizona & 14 & 8.8 & $25 \% / \$ 1 \mathrm{~K}$ & $\mathrm{Y}$ & & $\bar{Y}$ & & 7 & 10 & 2957 & 24 & $\$ 4,590$ & $\$ 456$ & $\$ 4,788$ \\
\hline Arkansas & 34 & 7.8 & & & & & & 7 & 7 & 2791 & 19 & $\$ 2,542$ & $\$ 434$ & $\$ 3,423$ \\
\hline Colorado & 10 & 7.4 & & $\mathrm{Y}$ & & & $25 \%$ & 10 & 16 & 4122 & 23 & $\$ 5,196$ & $\$ 687$ & $\$ 2,789$ \\
\hline Connecticut & 19 & 12.1 & & $\mathrm{Y}$ & & & & 6 & 4 & 2062 & 18 & $\$ 3,531$ & $\$ 319$ & $\$ 3,707$ \\
\hline Delaware & 21 & 9.2 & & & & & & 28 & 10 & 3503 & 18 & $\$ 3,497$ & $\$ 987$ & $\$ 2,910$ \\
\hline Florida & 11 & 8.1 & & & & $\mathrm{Y}$ & $\$ 2 / \mathrm{W}$ & 14 & 8 & 2739 & 19 & $\$ 5,016$ & $\$ 592$ & $\$ 2,544$ \\
\hline Georgia & 30 & 7.7 & & & & & & 17 & 7 & 3090 & 19 & $\$ 2,798$ & $\$ 687$ & $\$ 2,287$ \\
\hline Iowa & 23 & 8.2 & & $\mathrm{Y}$ & & & & 16 & 15 & 3497 & 19 & $\$ 2,995$ & $\$ 759$ & $\$ 1,915$ \\
\hline Kansas & 26 & 7.7 & & & & & & 9 & 12 & 3350 & 21 & $\$ 2,894$ & $\$ 576$ & $\$ 2,858$ \\
\hline Kentucky & 42 & 5.6 & & & & & & 27 & 11 & 2976 & 17 & $\$ 2,323$ & $\$ 930$ & $\$ 1,476$ \\
\hline Louisiana & 28 & 7.4 & & & & & & 19 & 8 & 3206 & 20 & $\$ 2,828$ & $\$ 735$ & $\$ 2,143$ \\
\hline Maine & 22 & 12.8 & & $\mathrm{Y}$ & & & & 8 & 3 & 2767 & 16 & $\$ 3,462$ & $\$ 423$ & $\$ 3,158$ \\
\hline Maryland & 7 & 8.3 & & $\mathrm{Y}$ & & & $\$ 2.94 / \mathrm{W}$ & 17 & 9 & 2876 & 18 & $\$ 6,133$ & $\$ 693$ & $\$ 2,744$ \\
\hline Massachusetts & 13 & 11.6 & $15 \% / \$ 1 \mathrm{~K}$ & $\mathrm{Y}$ & $\mathrm{Y}$ & $\mathrm{Y}$ & & 9 & 5 & 2408 & 18 & $\$ 4,647$ & $\$ 433$ & $\$ 4,321$ \\
\hline Michigan & 40 & 8.6 & & & & & & 11 & 8 & 2198 & 16 & $\$ 2,414$ & $\$ 481$ & $\$ 1,983$ \\
\hline Minnesota & 44 & 7.2 & & $\mathrm{Y}$ & $\mathrm{Y}$ & $\mathrm{Y}$ & & 7 & 10 & 2909 & 17 & $\$ 2,217$ & $\$ 469$ & $\$ 1,885$ \\
\hline Mississippi & 36 & 7.0 & & & & & & 11 & 9 & 3228 & 19 & $\$ 2,502$ & $\$ 581$ & $\$ 2,737$ \\
\hline New York & 1 & 14.1 & $25 \% / \$ 3750$ & $\mathrm{Y}$ & & & $50 \%$ & 6 & 4 & 1540 & 18 & $\$ 10,257$ & $\$ 289$ & $\$ 4,372$ \\
\hline N. Carolina & 5 & 8.0 & $40 \% / \$ 1500$ & $\mathrm{Y}$ & & & $\$ 2.94 / \mathrm{W}$ & 14 & 7 & 2409 & 19 & $\$ 7,042$ & $\$ 563$ & $\$ 3,714$ \\
\hline North Dakota & 20 & 6.3 & $5 \%-3 y r s$ & $\mathrm{Y}$ & $\mathrm{Y}$ & & & 15 & 12 & 3630 & 19 & $\$ 3,519$ & $\$ 710$ & $\$ 2,393$ \\
\hline Ohio & 25 & 8.6 & & & & & & 27 & 11 & 2714 & 16 & $\$ 2,956$ & $\$ 925$ & $\$ 2,354$ \\
\hline Oklahoma & 35 & 6.6 & & $\mathrm{Y}$ & & & & 9 & 12 & 3509 & 21 & $\$ 2,538$ & $\$ 578$ & $\$ 3,429$ \\
\hline Oregon & 47 & 5.6 & $.40 / \mathrm{kWh}, \$ 1 \mathrm{~K}$ & & & & & 1 & 1 & 415 & 18 & $\$ 2,042$ & $\$ 55$ & $\$ 2,344$ \\
\hline Pennsylvania & 8 & 9.9 & & $\mathrm{Y}$ & & & $\$ 2.94 / \mathrm{W}$ & 16 & 6 & 1854 & 16 & $\$ 6,092$ & $\$ 548$ & $\$ 3,052$ \\
\hline Rhode Island & 15 & 12.1 & & $\mathrm{Y}$ & & & $\$ 1 / \mathrm{W}$ & 1 & 9 & 2262 & 18 & $\$ 4,564$ & $\$ 264$ & $\$ 3,541$ \\
\hline S. Carolina & 41 & 7.5 & & & & & & 11 & 5 & 1738 & 19 & $\$ 2,403$ & $\$ 416$ & $\$ 2,598$ \\
\hline South Dakota & 46 & 7.1 & & & $\mathrm{Y}$ & & & 5 & 4 & 947 & 19 & $\$ 2,065$ & $\$ 215$ & $\$ 2,544$ \\
\hline Tennessee & 45 & 6.0 & & & & & & 18 & 7 & 2223 & 18 & $\$ 2,191$ & $\$ 652$ & $\$ 1,582$ \\
\hline Texas & 27 & 7.8 & & $\mathrm{Y}$ & $\mathrm{Y}$ & & & 6 & 9 & 3166 & 22 & $\$ 2,892$ & $\$ 453$ & $\$ 3,250$ \\
\hline Utah & 12 & 6.9 & $25 \% / \$ 2 \mathrm{~K}$ & & & & & 3 & 15 & 4705 & 24 & $\$ 4,907$ & $\$ 710$ & $\$ 2,588$ \\
\hline Vermont & 32 & 11.5 & & $\mathrm{Y}$ & & & & 0 & 0 & 293 & 16 & $\$ 2,614$ & $\$ 21$ & $\$ 3,198$ \\
\hline Virginia & 9 & 7.8 & & $\mathrm{Y}$ & & & $\$ 2.94 / \mathrm{W}$ & 12 & 6 & 2443 & 18 & $\$ 5,753$ & $\$ 513$ & $\$ 2,744$ \\
\hline Washington & 50 & 5.0 & & $\mathrm{Y}$ & & & & 2 & 1 & 412 & 15 & $\$ 1,020$ & $\$ 81$ & $\$ 1,084$ \\
\hline West Virginia & 33 & 6.3 & & & & & & 29 & 12 & 3353 & 17 & $\$ 2,605$ & $\$ 1,014$ & $\$ 2,105$ \\
\hline Wisconsin & 24 & 6.9 & & $\mathrm{Y}$ & $\mathrm{Y}$ & & $\$ 0.5 / \mathrm{kWh}$ & 14 & 10 & 2896 & 16 & $\$ 2,994$ & $\$ 630$ & $\$ 1,770$ \\
\hline Wyoming & 38 & 6.2 & & & & & & 8 & 16 & 4151 & 21 & $\$ 2,477$ & $\$ 641$ & $\$ 1,887$ \\
\hline
\end{tabular}


Net metering [6], property tax, and sales tax [4] incentives are included in the table, but not in the analysis. Full residential electric rate benefits are assumed, due to the BTC per $\mathrm{kW}$ installed basis.

The state buy-downs and grants are all new policies that have developed since the original study. The authors have chosen to include two state (Florida and Illinois) buy-down policies and programs, which are not yet, but will soon be, available. However, the actual buy-down may change upon availability. Additionally, the authors were unable to verify the availability of the Colorado Solar Energy Association 25\% system cost rebate, but the rebate is included in the analysis.

The California SBC provides \$54 million over 4 years for buy-downs of "emerging renewables," which include residential CSPV. The California Energy Commission administers the fund, which started in March of 1998. The buy-down provides $\$ 3 / \mathrm{W}$, up to $50 \%$ of the installed cost. It was designed to decline on an annual basis, but is currently still available at the $\$ 3 / \mathrm{W}$ value [12].

The Photovoltaic Buildings in Florida program will apply the major portion of $\$ 600,000$ worth of funding from the Florida Energy Office / Department of Community Affairs toward system buy-downs. The residential CSPV buy-down is proposed at \$2/W [8]. The program will be administered by the Florida Solar Energy Center.

The Illinois SBC will collect \$5 million annually targeted towards renewable energy resources [5]. The Renewable Energy Resources Program, under the Department of Commerce and Community Affairs, is expected to administer grants to fund $60 \%$ of CSPV costs up to $\$ 5,000$.

The Virginia Alliance for Solar Energy (VASE) is currently offering a $\$ 2.94 / \mathrm{W}$ buy-down for residential CSPV in five states (Maryland, New Jersey, North Carolina, Pennsylvania and Virginia) through a request for proposal [7]. A minimum aggregate of $10 \mathrm{kWac}$ is required by the request for proposal.
The New York State Energy Research and Development Authority (NYSERDA) will administer the SBC fund, expected to collect over \$234 million in the next three years [5]. Currently, NYSERDA has a program opportunity notice (PON) to deploy $\$ 1$ million funds toward residential CSPV [9]. The PON limits the cost share at $50 \%$.

The pounds per kilowatt-hour emission mitigation for $\mathrm{SO}_{\mathrm{X}}, \mathrm{NO}_{\mathrm{X}}$, and $\mathrm{CO}_{2}$ externalities were determined using the total industry generation and total industry emissions for each state [10]. Due to disclosure conflicts and externalities conflicts, six states (Arizona, Kentucky, Mississippi, Nebraska, North Dakota, and Wyoming) are calculated using utility generation and total industry emissions. The emissions mitigated for each $\mathrm{kW}$ of PV installed are then calculated using the state average PV capacity factor [11]. The value of the emissions mitigation by PV is based on the cost of control [15] versus the value of environmental damages.

TABLE 2: Emissions Cost-of-Control Values

\begin{tabular}{|l|l|l|l|l|}
\hline & National [14] & CA [16] & WI [16] & MA 16] \\
\hline $\begin{array}{l}\mathrm{SO}_{\mathrm{X}} \\
\$ / \#\end{array}$ & $\$ 2.03$ & $\$ 2.20-11.00$ & NA & $\$ 0.75$ \\
\hline $\begin{array}{l}\mathrm{NO}_{\mathrm{X}} \\
\$ / \#\end{array}$ & $\$ 0.82$ & $\$ 4.50-\$ 15.00$ & $\$ 1.35$ & $\$ 3.25$ \\
\hline $\begin{array}{l}\mathrm{CO} \\
\$ / \text { ton }\end{array}$ & $\$ 13$ & $\$ 9$ & $\$ 15$ & $\$ 22$ \\
\hline
\end{tabular}

\section{RESULTS}

As shown in Figure 1, fifteen states now have BTCs above $\$ 4 / \mathrm{W}$. In just four years, 12 new state policies, either buy-downs, grants, or state income tax rebates, have been instituted, all of which reduce the initial cost of the CSPV system, increasing the BTC. Figure 2 examines the top fifteen states for other potential policies, such as environmental externalities and real-time pricing.

FIGURE 1 Breakeven Turnkey Cost 1996 \& 1999

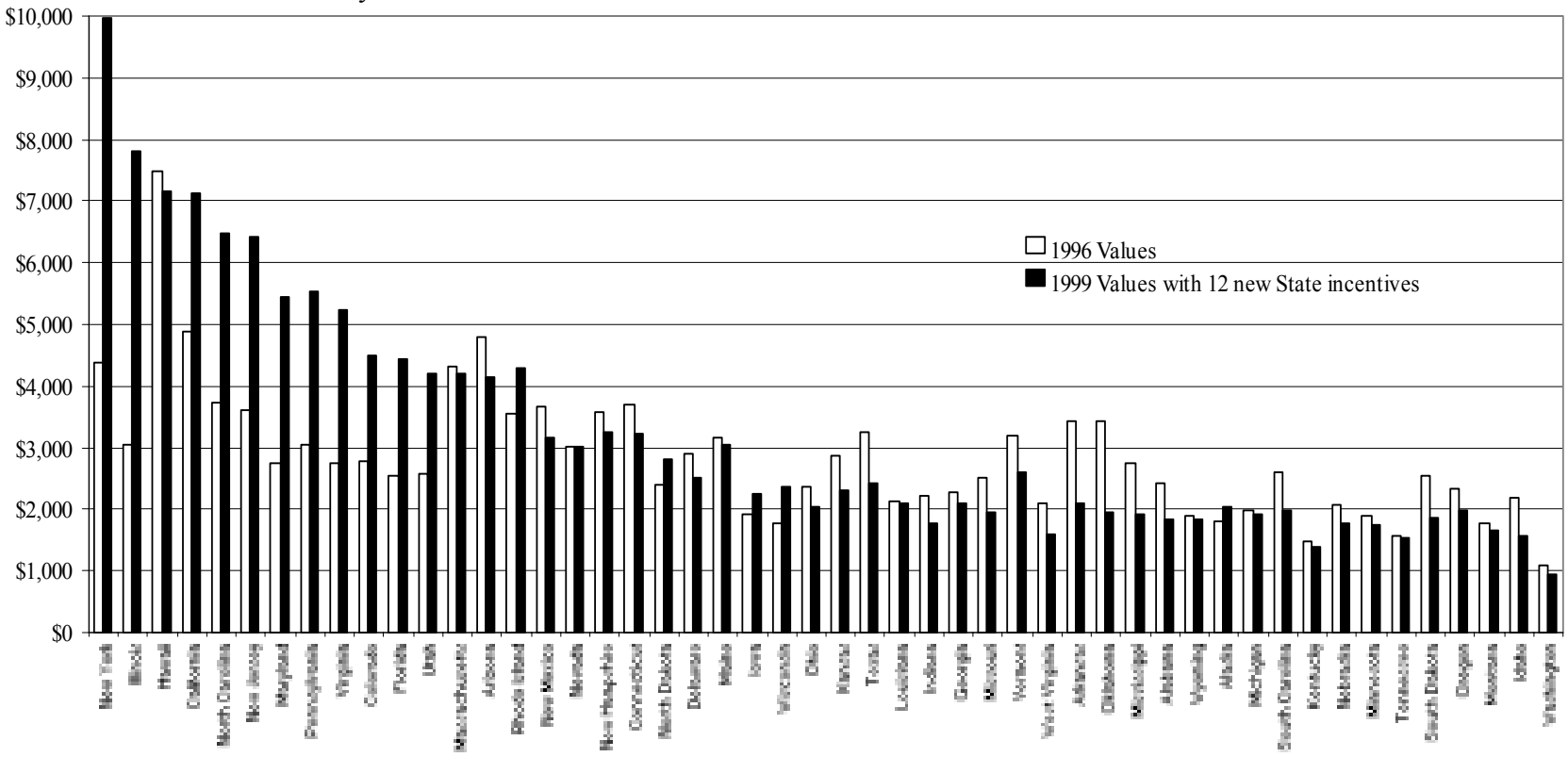


Figure 2: 1999 BTC with Environmental Externalities and Real Time Pricing

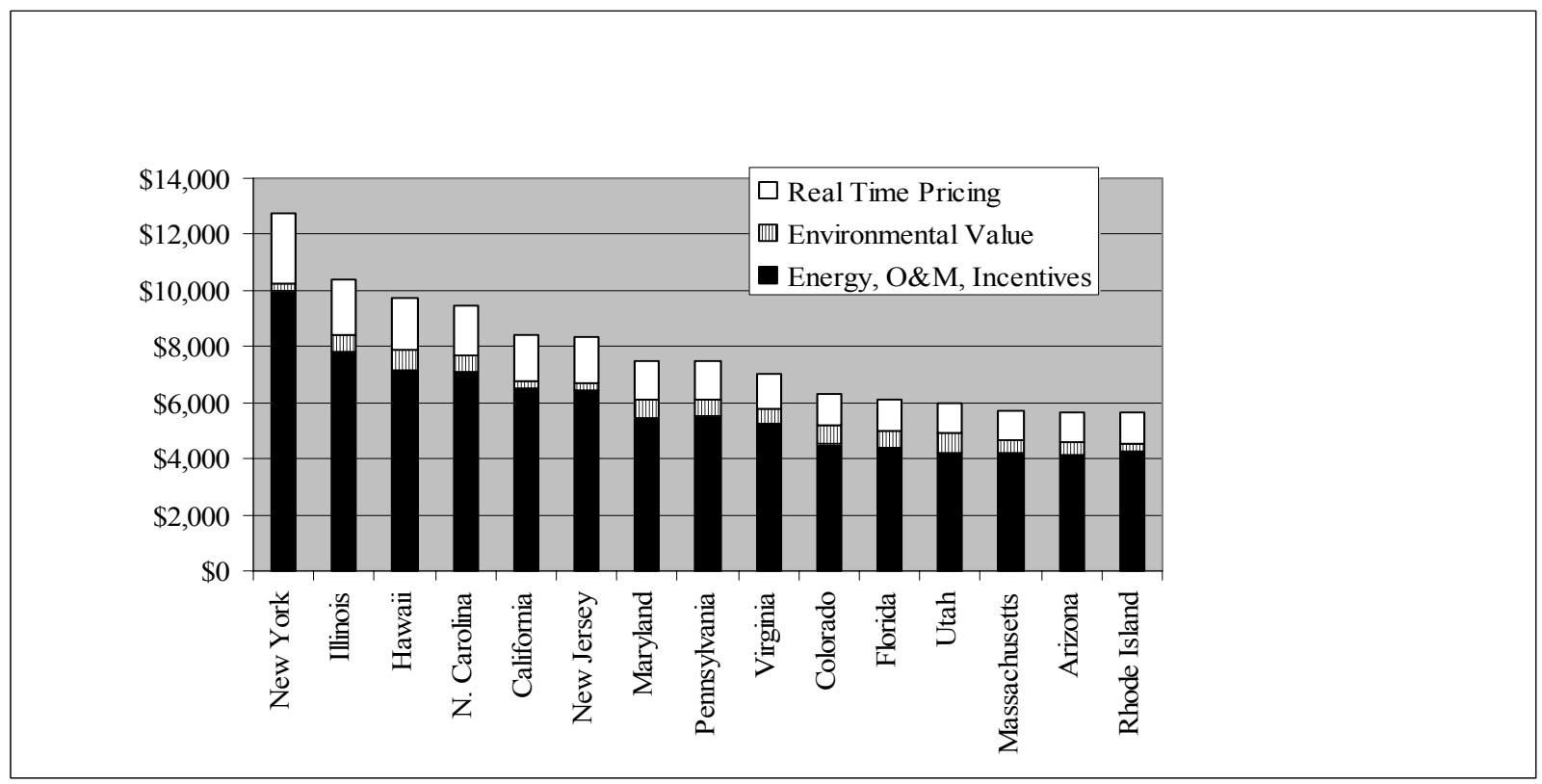

\section{CONCLUSIONS}

The economics indicate policies do effectively fill the gap between consumer value and price. The most active deployment areas in the country are the states with high BTCs.

Though many of the incentives used in the analysis have changed or sunseted, there is potential for new incentives. Currently, 23 states have initiated or implemented restructuring policies and 16 have renewables provisions. The system benefits charges (SBC), included in 13 state restructuring policies, are a source of funding for consumer incentives. Thus far, only 7 of the 13 state SBCs have been implemented, leaving potential for more near-term incentives. Additionally, 9 state renewable portfolio standards, the Million Solar Roofs initiative, $40+$ community partnerships working on consumer awareness, reducing infrastructure barriers and municipal policies, and the fifty utility green-pricing programs either offered or under development are potentially new arenas for consumer incentives.

With the potential for market stimulation through policy incentives established by analyzing the increased consumer value, the next step is to determine the effectiveness as measured by participation in the various incentives programs.

\section{REFERENCES}

[1] Wenger, H., Herig, C., Taylor, R., Eiffert, P., and R. Perez, "Niche Markets For Grid-Connected Photovoltaics", IEEE Photovoltaic Specialists Conference, Washington, D.C., 10/96

[2] Osborn, D., "Sustained Orderly Development and Commercialization of Grid-Connected Photovoltaics: SMUD as a Case Example", A pre-print from Advances in Solar Energy XIV, 2000, Ver. 02/24/2000
[3] Energy Information Administration, "Electric Sales and Revenue 1997"

[4] Database of State Incentives for Renewable EnergyDSIRE, (1998). NCSC-IREC@ http://wwwsolar.mck.ncsu.edu/dsire.htm

[5] Sprately, W. A., "Consumer Charges Power Solar Financing", Public Utilities Fortnightly, Dec. 1998

[6] Starrs, T. (Feb. 1999), Personal Communications, "Summary of State Net Metering Programs (current)", version 2/15/99, Kelso Starrs and Assoc., Vashon, WA

[7] VASE Request for Proposal Phase 3, Virginia Alliance for Solar Energy (VASE) @ http://www.vase.org/index.html, (1999)

[8] Ventre, G. (1999), Personal Communication, Florida Solar Energy Center, Cocoa, FL

[9] Program Opportunity Notice (PON) No. 448-98, "Residential Photovoltaics Market Development", New York Solar Energy Research and Development Authority (NYSERDA) @ http://www.nyserda.org/448pon.html, 1999

[10] Energy Information Administration, "State Electricity Profiles", DOE/EIA-0629, March 1999

[11] QuickScreen software, Pacific Energy Group @ http://www.pacificenergy.com/software.htm

(12) Masri, M. (1999): Personal Communications, California Energy Commission, Sacramento, CA

[13] Osborn, D., "Commercialization and Business Development of Grid-Connected PV at SMUD", Proc. ASES Solar '98 Conference, Albuquerque, NM, June 1998

[14] Buchanan, C., P. Chernick, A. Krupnik, U. Fritsche, (1991) Environmental Costs of Electricity, Oceana

[16] Energy Information Administration, "Electricity Generation and Environmental Externalities: Case Studies”, DOE/EIA-0598, March 1999 


\section{REPORT DOCUMENTATION PAGE}

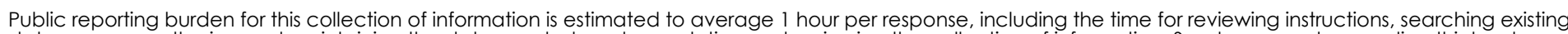

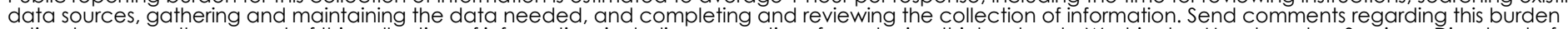

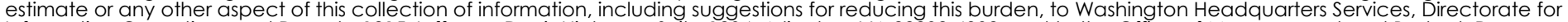

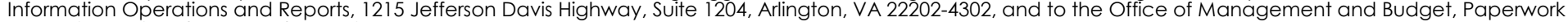
Reduction Project (0704-0188), Washington, DC 20503.

\begin{tabular}{|l|l|l|l|}
\hline 1. AGENCY USE ONLY (Leave blank) & $\begin{array}{l}\text { 2. REPORT DATE } \\
\text { May } 2000\end{array}$ & $\begin{array}{l}\text { 3. REPORT TYPE AND DATES COVERED } \\
\text { conference paper }\end{array}$ \\
\hline
\end{tabular}

4. TITLE AND SUBTITLE

Customer-Sited PV-U.S. Markets Developed from State Policies

6. AUTHOR(S)

C. Herig, H. Thomas, R. Perez, and H. Wenger

7. PERFORMING ORGANIZATION NAME(S) AND ADDRESS(ES)

9. SPONSORING/MONITORING AGENCY NAME(S) AND ADDRESS(ES)

National Renewable Energy Laboratory

1617 Cole Blvd.

Golden, CO 80401-3393

1. SUPPLEMENTARY NOTES

12a. DISTRIBUTION/AVAILABILITY STATEMENT

National Technical Information Service

U.S. Department of Commerce

5285 Port Royal Road

Springfield, VA 22161

13. ABSTRACT (Maximum 200 words)

The customer-sited PV market in the United States depends on state policies emerging from electric utility industry restructuring. These policies, most of which have appeared since 1996, reduce both the first cost and improve operating benefits. This analysis determines the breakeven turnkey cost of a PV system, from the customer ownership perspective, on a state by state basis. The results of this work are used by industry to target high-value markets and by policy makers to identify options which will result in the greatest economic and market development. Still intangible external PV benefits, such as environmental value, are also analyzed and gauged against existing/potential policy actions.

\section{SUBJECT TERMS}

photovoltaics ; PV markets ; PV systems ; customer-sited PV ; state policies ; break-even turnkey cost

17. SECURITY CLASSIFICATION

OF REPORT

Unclassified

18. SECURITY

CLASSIFICATION

OF THIS PAGE

Unclassified
15. NUMBER OF PAGES

16. PRICE CODE

19. SECURITY CLASSIFICATION OF ABSTRACT

Unclassified
20. LIMITATION OF ABSTRACT

UL 